\title{
Lactose levels in diets for piglets weaned at 21 days of age
}

\author{
Juliano Pelição Molino ${ }^{1}$, Juarez Lopes Donzele ${ }^{2}$, Rita Flávia Miranda de Oliveira², Aloízio Soares \\ Ferreira $^{2}$, Célia Alencar de Moraes ${ }^{3}$, Douglas Haese ${ }^{4}$, Alysson Saraiva ${ }^{1}$, João Paulo de Oliveira ${ }^{5}$
}

1 Programa de Pós-graduação em Zootecnia - UFV, Viçosa - MG, Brasil.

2 Departamento de Zootecnia/UFV.

${ }^{3}$ Departamento de Microbiologia/UFV.

${ }^{4}$ Centro Universitário Vila Velha, Vila Velha - ES, Brasil.

${ }^{5}$ Curso de Graduação em Zootecnia/UFV.

ABSTRACT - With the objective of evaluating levels of lactose in diets for piglets weaned at 21 days of age, it was carried out an experiment with 72 animals, with average weight of $6.12 \mathrm{~kg}$, distributed in a completely randomized block design with four diets $(0,4,8$, and $12 \%$ lactose), six replicates, and 3 animals per experimental unit. Animals were fed the experimental diets from 21 to 35 days of age and they were fed a lactose-free basal diet from 36 to 49 days of age. The lactose levels did not affect daily weight gain, feed intake and feed conversion of piglets from 21 to 35 days of age. The use of lactose levels in the diets also did not affect performance of the piglets assessed from 21 to 49 days old. Diets also did not influence villous height, crypt depth and villous:crypt ratio. Lactose resulted in greater diversity and balance of the intestinal microbial community. The Lactobalillus spp. richness increases with the addition of lactose in diet up to the level of $8 \%$ in relation to the total number of intestinal microorganisms, which may a possible improvement of intestinal health.

Key Words: intestinal microbiota, microbial diversity, mucosal structure, weaning

\section{Níveis de lactose em rações para leitões desmamados aos 21 dias de idade}

\begin{abstract}
RESUMO - Com o objetivo de avaliar níveis de lactose em rações para leitões desmamados aos 21 dias de idade, foi realizado um experimento com 72 animais com peso inicial médio de $6,10 \mathrm{~kg}$, distribuídos em delineamento de blocos ao acaso com quatro rações $(0,4,8$ e $12 \%$ de lactose), seis repetições e três animais por unidade experimental. Os animais foram alimentados com as rações experimentais no período de 21 a 35 dias de idade e, no período de 36 a 49 dias, receberam uma ração basal isenta de lactose. Os níveis de lactose não afetaram o ganho diário de peso, o consumo diário de ração e a conversão alimentar dos leitões de 21 a 35 dias. O uso de lactose nas rações também não afetou o desempenho dos leitões avaliados dos 21 aos 49 dias de idade. As rações também não influenciaram a altura das vilosidades, a profundidade de criptas e a relação vilosidade:cripta. A lactose proporcionou maior diversidade e equilíbrio da comunidade microbiana intestinal. A riqueza microbiana de Lactobacillus spp. aumenta com a adição de lactose na ração até o nível de $8 \%$ em relação ao número total de microrganismos intestinais, o que indica possível melhora da saúde intestinal.
\end{abstract}

Palavras-chave: desmama, diversidade microbiana, microbiota intestinal, morfometria de mucosa

\section{Introduction}

The major problems caused at weaning have been linked to the decrease in feed intake of piglets. When feed intake is satisfactory, there is an overall increase in the secretion of gastrointestinal hormones resulting in increased cell proliferation in the crypts of the intestinal epithelium, followed by an augment of the villi length (Herdt, 1999).

The subtle diet change associated with the weaning processes implies in the efficiency at with piglets digest and absorb the nutrients consumed, which in turn will reflect on the villous height and crypt depth of the small intestinal mucosa (Pluske et al., 1996). The lower capacity of nutrients utilization by the piglets, whose villi are decreased, may be related to a lower mucosa surface area in contact with feed.

In the weaning process, at 21 days of age, there is an abrupt change in the feed of piglets from the milk of the sow to a dry diet mainly composed by corn and soybean meal. When feed composition is altered, changes can also occur in the intestinal microbiota composition inasmuch as the microbial activity is directly affected by the substrate supplied (Williams et al., 2001).

Intestinal microbiota of piglet can be analyzed by its diversity and richness. The diversity index refers to the variety of microorganisms species found in a determined 
portion in the intestine and it is composed by uniformity and richness of the species. The richness, in turn, makes reference to the numeric quantities of groups of species and it is represented by operational taxonomic units (Odum, 1993).

Many ingredients, lactose among them, have been evaluated focusing in the potential to improving performance of piglets during the first weeks after weaning. However, the effects of adding lactose in the diet, especially concerning to the intestinal microbiota composition, has not been well studied.

Thus, the objective of this study was to evaluate the effect of dietary lactose levels on performance, structure of the small intestinal mucosa, and large intestinal microbiota composition of piglets weaned at 21 days of age.

\section{Material and Methods}

The study was conducted at the Setor de Suinocultura do Departamento de Zootecnia at Universidade Federal de Viçosa (UFV), Viçosa, MG-Brazil.
Seventy-two commercial hybrid piglets, weaned at $21 \pm 1$ day, with initial body weight of $6.10 \pm 0.60 \mathrm{~kg}$ were used, distributed in a completely randomized block design with four diets, six replicates, and three piglets per experimental unit. Body weight at weaning and relationship among piglets were used as the criteria in formation of the blocks. The diets provided from 21 to 35 days contained $0,4,8$, and $12 \%$ lactose. From 36 to 49 days of age, all piglets were fed the same diet with no lactose.

The experimental diets from 21 to 35 days of age (Table 1) and from 36 to 49 days of age (Table 2) containing the same levels of ME, lysine, calcium, and phosphorus were formulated to meet nutritional requirements of piglets at pre-starter and initial phases ( 7 to $15 \mathrm{~kg}$ ), as recommended by Rostagno et al. (2005).

Pigs were housed in suspended metal cages, with wired floors and sides, equipped with semi-automatic feeders and drinkers, located in a concrete building with concrete floor, and lowed wooden roof covered with French clay tile.

Table 1 - Proximate composition and nutritional values of experimental diets given to animals from 21 to 35 days of age

\begin{tabular}{|c|c|c|c|c|}
\hline \multirow[t]{2}{*}{ Ingredient } & \multicolumn{4}{|c|}{ Lactose level $(\%)$} \\
\hline & 0 & 4 & 8 & 12 \\
\hline Corn & 53.09 & 50.97 & 46.17 & 41.29 \\
\hline Soybean meal $(45 \%)$ & 17.00 & 17.00 & 17.00 & 17.00 \\
\hline Cristalin lactose & - & - & 4.08 & 8.16 \\
\hline Milk powder & - & 7.70 & 7.70 & 7.70 \\
\hline Dicalcium phosphate & 1.97 & 1.76 & 1.76 & 1.76 \\
\hline Limestone & 0.64 & 0.57 & 0.57 & 0.57 \\
\hline Salt & 0.41 & 0.33 & 0.33 & 0.33 \\
\hline Vitamin premix ${ }^{1}$ & 0.40 & 0.40 & 0.40 & 0.40 \\
\hline Mineral premix ${ }^{2}$ & 0.24 & 0.24 & 0.24 & 0.24 \\
\hline Growth promoter ${ }^{3}$ & 0.05 & 0.05 & 0.05 & 0.05 \\
\hline \multicolumn{5}{|l|}{ Nutritional calculated composition ${ }^{4}$} \\
\hline ME (kcal/kg) & 3400 & 3400 & 3400 & 3400 \\
\hline Crude protein $(\%)$ & 22.78 & 22.96 & 23.93 & 22.89 \\
\hline Lactose $(\%)$ & 0.00 & 4.00 & 8.00 & 12.00 \\
\hline Digestible lysine (\%) & 1.40 & 1.40 & 1.40 & 1.40 \\
\hline Digestible Methionine + Cystine (\%) & 0.78 & 0.78 & 0.78 & 0.78 \\
\hline Digestible Threonine (\%) & 0.88 & 0.88 & 0.88 & 0.88 \\
\hline Digestible Tryptophan (\%) & 0.26 & 0.26 & 0.26 & 0.26 \\
\hline Calcium (\%) & 0.85 & 0.85 & 0.85 & 0.85 \\
\hline Total phosphorus (\%) & 0.66 & 0.66 & 0.66 & 0.66 \\
\hline Available phosphorus (\%) & 0.50 & 0.50 & 0.50 & 0.50 \\
\hline
\end{tabular}


the Shannon-Weaver diversity (H') and equitably (E') indexes, and the similarity corresponding to the diets containing different lactose levels.

The richness was obtained based on a binary matrix in which the absence of the DNA band corresponding to each OUT was codified as zero and the presence as 1 . For each lactose level the frequency of occurrence of each OUT was obtained by counting the number of presences. The H' and E' were calculated through the equations used by Dilly et al. (2004). The H' index was calculated based on the abundance expressed as the band optical density in the gel lane, by the equation:

$H^{\prime}=\frac{2.3}{N}\left(N \log N-\sum n i \log n i\right)$,

where: $\mathrm{N}=$ optical density in the lane, obtained by the sum of the bands optical densities in the lane, $\mathrm{ni}=$ optical density of each band in the lane.

E' was calculated as:

$E=\frac{H^{\prime}}{\log R}$

The performance and intestinal mucosa structure data were subjected to the variance analysis and $\mathrm{F}$ test at $5 \%$ of probability, and regression by using the program SAEG (Sistemas para Análises Estatísticas e Genéticas), developed at Universidade Federal de Viçosa-MG (UFV, 2001).

\section{Results and Discussion}

The temperature in the nursery room during the experimental period were kept at $26.3 \pm 1.49^{\circ} \mathrm{C}$ (minimum) and $30.0 \pm 1.12^{\circ} \mathrm{C}$ (maximum). Dry bulb temperatures registered at 8:00 a.m., 12:00 p.m., and 5:00 p.m. were $26.1 \pm 2.6 ; 27.6 \pm 1.2$ and $27.4 \pm 2.8^{\circ} \mathrm{C}$, and the relative humidity values were $68 \pm 8.1 ; 61 \pm 10.5$, and $61 \pm 9.3 \%$, respectively. The Black Globe Humidity Index (BGHI) calculated at 8:00 a.m., 12:00 p.m., and 5:00 p.m. were $77.7 \pm 1.6,78.3 \pm 1.3$, and $78.4 \pm 1.6$, respectively. Considering that according to Campos et al. (2008) BGHI indexes up to 80 characterize ambient of thermal comfort for piglets at the initial phase of growth, it can be inferred that the temperature registered in the present study were in the range of thermoneutrality.

The lactose levels did not influence $(\mathrm{P}>0.05)$ performance of piglets from 21 to 35 days of age (Table 3 ). This result is in accordance with those found by Pollmann et al. (1980), who working with piglets weighing in average $6.0 \mathrm{~kg}$ at weaning also did not found significant effect in daily weight gain (DWG) and feed conversion (FC), assessed weekly until 28 days after weaning, by adding $10 \%$ lactose in the diets.

Carrying out three studies to evaluate carbohydrates sources, including lactose, in diets for weaned piglets, Naranjo et al. (2010) obtained inconsistent results and noticed that lactose levels had positive effects on performance of piglets at the first week after weaning only in one of the studies.

On the other hand, Mahan et al. (2004) in a work with piglets weaned at 19 days of age and fed diets containing 10 to $35 \%$ of lactose at the first two weeks post weaning and with $17 \%$ (fixed level) in the next weeks ( 15 to 30 days after weaning), verified linear increase in $\mathrm{AWG}$ of piglets from 0 to 7 and 7 to 14 days, and improved FC only in the first week of weaning.

Positive effect of lactose in performance of piglets was also observed by Bertol et al. (2000) who studying lactose levels up to $21 \%$ in diets for piglets weaned at 21 days of age found feed intake $(\mathrm{FI})$ and $\mathrm{AWG}$ linearly increased $(\mathrm{P}<0.05)$, and that $\mathrm{FC}$ improved $(\mathrm{P}<0.08)$ also in a linear way on the first 14 days post weaning. Similarly, other authors observed

Table 3 - Performance of piglets from 21 to 35 days of age fed diets with lactose

\begin{tabular}{|c|c|c|c|c|c|}
\hline & \multicolumn{4}{|c|}{ Lactose level* } & \multirow[t]{2}{*}{$\mathrm{CV} \%$} \\
\hline & 0 & 4 & 8 & 12 & \\
\hline & \multicolumn{4}{|c|}{ From 21 to 35 days } & \\
\hline Initial weight & 6.11 & 6.09 & 6.07 & 6.16 & 1.04 \\
\hline Weight at 35 days of age & 8.84 & 9.50 & 9.14 & 9.63 & 5.87 \\
\hline Daily weight gain & 195 & 244 & 220 & 248 & 17.22 \\
\hline Daily feed intake & 250 & 308 & 280 & 306 & 13.34 \\
\hline \multirow[t]{3}{*}{ Feed conversion } & 1.29 & 1.28 & 1.28 & 1.25 & 9.45 \\
\hline & \multicolumn{4}{|c|}{ From 21 to 49 days } & $\mathrm{CV} \%$ \\
\hline & $0-0$ & $4-0$ & $8-0$ & $12-0$ & \\
\hline Initial weight & 6.11 & 6.09 & 6.11 & 6.16 & 1.04 \\
\hline Weight at 49 days of age & 15.96 & 16.12 & 14.86 & 16.11 & 11.34 \\
\hline Daily weight gain & 352 & 358 & 312 & 356 & 17.55 \\
\hline Daily feed intake & 481 & 412 & 450 & 493 & 15.20 \\
\hline Feed conversion & 1.36 & 1.43 & 1.45 & 1.4 & 6.25 \\
\hline
\end{tabular}

*Not significant $(\mathrm{P}>0.05) ; \mathrm{CV}=$ coefficient of variation. 
linear increase $(\mathrm{P}<0.14)$ in $\mathrm{AWG}$ throughout the experimental period and in the average body weight of pigs at 28 days of age.

Working with piglets weaned at 24 days of age and average weight of $7.1 \mathrm{~kg}$, Pierce et al. (2005) also found significant increase in the growing rate of pigs as a result of increasing the level of lactose in the diet.

By taking into account the benefits attributed to lactose reported by Pierce et al. (2006) such as improvement of the intestinal health through intestinal $\mathrm{pH}$ reduction, increase in Lactobacillus spp., and decrease in populations of Coliformes spp., it can be inferred that the presence of antimicrobial and blood plasma in the diets may have contributed for the lack of effect in performance of piglets by increasing dietary lactose.

According to Yen et al. (1987), the positive effect of antibiotic in the performance of pigs is related to the inhibition of development of gastrointestinal microorganisms such as pathogenic Escherichia coli. Thus, it is possible to deduce that in the presence of antibiotics as growth promoters in diets for pigs, the functionality of ingredients with potential to improve the intestinal health and, consequently, performance, like lactose, may be reduced. Confirming the possible interaction between lactose and antibiotic in the diet, Pierce et al. (2005) evaluated two dietary lactose levels (17.5 and 29.5\%) with or without antibiotic for piglets during the post weaning period and found that the increase in the lactose level only improved performance of piglets when diets were antibiotic free.

In spite of blood plasma effects influencing responses of pigs to dietary lactose levels, Touchette et al. (1995) found that by adding plasma spray dried in the diet decreased the need of lactose from about 30 to $40 \%$ to 0 to $15 \%$ to maximize' performance of weaned piglets.

The dissonance observed among some performance results occasioned by the inclusion of lactose in diets for weaned piglets (Naranjo et al., 2010; Pollmann et al., 1980; Mahan et al., 2004; Bertol et al., 2000; Pierce et al., 2005; Pierce et al., 2006; Yen et al., 1987; Touchette et al., 1995) may be related to differences in the level of immune challenge which the pigs were exposed to and to the composition of the diets.

The statement that the level of immune challenge can interfere in the performance of piglet response to the lactose in the diet is consistent with the results of Cromwell et al. (2008) who evaluated lactose levels up to $10 \%$ for post weaned piglets in three different experimental units and found significant effect of the experimental unit in the average daily gain and feed conversion. The authors noticed the best performance of piglets observed in one of the units was related to its better sanitary condition. Consistent with this result, Vente-Spreeuwenberg et al. (2003) assessed the inclusion of lactose compared to glucose or starch in diets of weaned piglets and reported that the response of the piglets to the diets was dependent of their sanitary level.

In the present study, diarrhea was not observed in piglets fed diets containing lactose what would be an indicative that piglets were exposed to a low level of sanitary challenge.

By studying the interaction between crude protein (16 and $20 \%$ ) and lactose (5 and 23\%) in diets for piglets at first weeks post weaning, Lynch et al. (2009) found positive effect of the highest lactose level (23\%) in performance of the piglets only when the diet with the highest protein level was given to the piglets. Similarly, Pierce et al. (2007) also found that the performance of the piglets in response to lactose levels was positively related to the crude protein level in the diet. In the same way, O'Connell et al. (2005) verified the level of lactose that resulted in the greatest performance of the pigs varied with the cereal (wheat or barley) used in the diets.

There was no effect $(\mathrm{P}>0.05)$ of dietary lactose in the intestinal mucosa structure (Table 4). Similar results were obtained by Spreeuwenberg et al. (2001), who evaluated the performance and the intestinal mucosa structure of early weaned piglets and did not found effect in the villous height by adding lactose to the diets.

Pierce et al. (2006) studied the effect of dietary lactose on the intestinal morphology of post weaned piglets and found no variation in the villi height and cryptas depth in segments of the small intestine.

The mucosa structure observed in this study did not confirm those data of Pluske et al. (1996), Bertol et al. (2000), Mahan et al. (2004), and Pierce et al. (2005).

Table 4 - Small intestinal mucosa structure of piglets at 49 days of age corresponding to the portioins of duodenum, jejunum e ileum

\begin{tabular}{|c|c|c|c|c|c|}
\hline & \multicolumn{4}{|c|}{ Lactose* } & \multirow[t]{2}{*}{$\mathrm{CV}(\%)$} \\
\hline & 0 & 4 & 8 & 12 & \\
\hline \multicolumn{6}{|l|}{ Duodenum } \\
\hline Villous heigth & 502 & 457 & 488 & 519 & 10.01 \\
\hline Crypt depth & 216 & 213 & 216 & 233 & 15.80 \\
\hline Villous:cripta & 2.36 & 2.23 & 2.30 & 2.25 & 11.94 \\
\hline \multicolumn{6}{|l|}{ Jejunum } \\
\hline Villous heigth & 467 & 435 & 424 & 444 & 11.90 \\
\hline Crypt depth & 204 & 209 & 195 & 202 & 13.55 \\
\hline Villous:cripta & 2.42 & 2.17 & 2.37 & 2.35 & 10.40 \\
\hline \multicolumn{6}{|l|}{ Ileum } \\
\hline Villous heigth & 389 & 402 & 387 & 394 & 6.66 \\
\hline Crypt depth & 185 & 171 & 158 & 170 & 13.72 \\
\hline Villous:cripta & 2.15 & 2.36 & 2.42 & 2.38 & 12.56 \\
\hline
\end{tabular}


For the intestinal microbiota evaluation the results of microbial richness (Figure 1), measured in operational taxonomic units (OUT) showed an increase in the Lactobacillus spp. up to $8 \%$ of lactose in the diet compared to the total eubacteria richness which was not influenced by the lactose levels. Microbial richness (R) can be understood as an indicator of microorganism quantity present in a certain environment and an increase in the R of Lactobacillus spp. of digesta of piglets can be associated to their intestinal health. As reported by Williams et al. (2001) the improvement in the enteric health occurs due to the fermentation of carbohydrates such as lactose in the large intestine. These results are in agreement with those found by Pollmann et al. (1980), Pierce et al. (2005), Pierce et al. (2006), Pierce et al. (2007), Cromwell et al. (2008), and Liu et al. (2008), who confirmed lactose is the preferred substrate for bacteria producing lactic acid as Lactobacillus spp. and Bifdobacteria spp. Yet, according to Stewart et al. (1993) the capacity of these bacteria to reduce digesta $\mathrm{pH}$ through lactic acid production constitutes a barrier against the colonization by pathogenic bacteria like Coliformes spp.

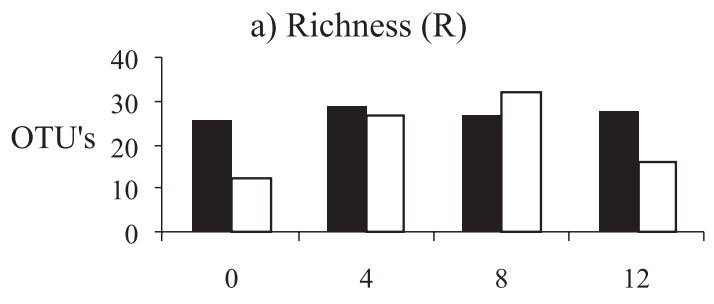

b) Shannon-Weaver diversity index

(H')

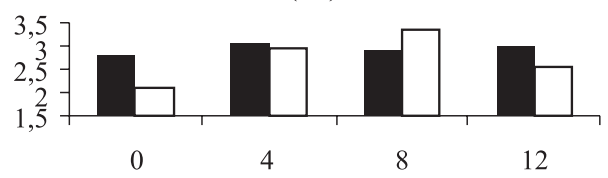

c) Equitability index (E')

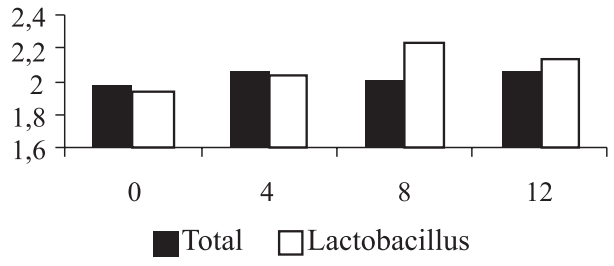

Figure 1 - a) Richness (R); b) Shannon-Weaver diversity index $\left(\mathrm{H}^{\prime}\right)$, and c) Equitability index (E) of bacterial communities in the intestinal content of piglets fed diets with $0,4,8$, and $12 \%$ lactose, for total Eubacteria and Lactobacillus spp.
In addition to favoring the Lactobacillus spp. microbial richness regarding to the total bacterial community, the diversity of Lactobacillus spp. strains, as well as the equilibrium among theses strains were also affected by increasing lactose level up to $8 \%$, what can be verified by the Shannon-Weaver and equitability indexes found (Figure 1), respectively.

Results found by Delcenserie et al. (2008) with humans confirmed that diversity of different Lactobacillus spp. strains in the intestine has a beneficial effect to the enteric health of the host as the diversity gives greater capacity for modulation of various inflammatory responses, increasing the defense capacity against intestinal microorganisms with pathogenic potential.

Although the effect of increasing lactose levels on the microbiota has been fairly consistent, it was found that richness, Shannon-Weaver and equitability of Lactobacullus spp. indexes reduced when lactose level increased from 8 to $12 \%$, and this suggests that $12 \%$ of lactose in the diet may have inhibited the growth of some group.

The observation of the DGGE gels of digesta content of the proximal colon of piglets fed diets containing $0,4,8,12 \%$ of lactose for Eubacteria and specific for Lactobacillus spp. (Figure 2) showed the occurrence of similar banding patterns among animals fed diets containing lactose, in the same gel, with the presence of bands with the alignment and well colored among all gel lanes. The bacterial communities there represented are probably stable populations of microorganisms based in the conditions of collection site despite the differences between sampled areas. The electrophoretic DGGE profiles confirmed the existence of differences among bands of different diets.

The grouping by similarity observed in the Eubacteria gel clearly demonstrated $80 \%$ similarity between piglets fed diets with 0 and $4 \%$ lactose and $69.1 \%$ similarity between those fed diets with 8 and $12 \%$ lactose

Bacteria, in general, are not randomly distributed along the gastrointestinal tract but the species and population levels are distributed according to specific characteristics of regions of the tract. This specificity results in $\mathrm{pH}$ differences, presence of digestive enzymes and bile salts which can modify the intestinal microenvironments where the bacterial community can also be different (Pedroso et al., 2005). Thus, it is accepted that diet is the main factor that determines the composition of the bacterial population in the intestinal lumen of animals (Pluske et al., 1997), which would explain the $64.4 \%$ of similarity found in the microbiota among piglets whose diets contained 4 and $8 \%$ lactose concerned to the Lactobacillus spp. population. 


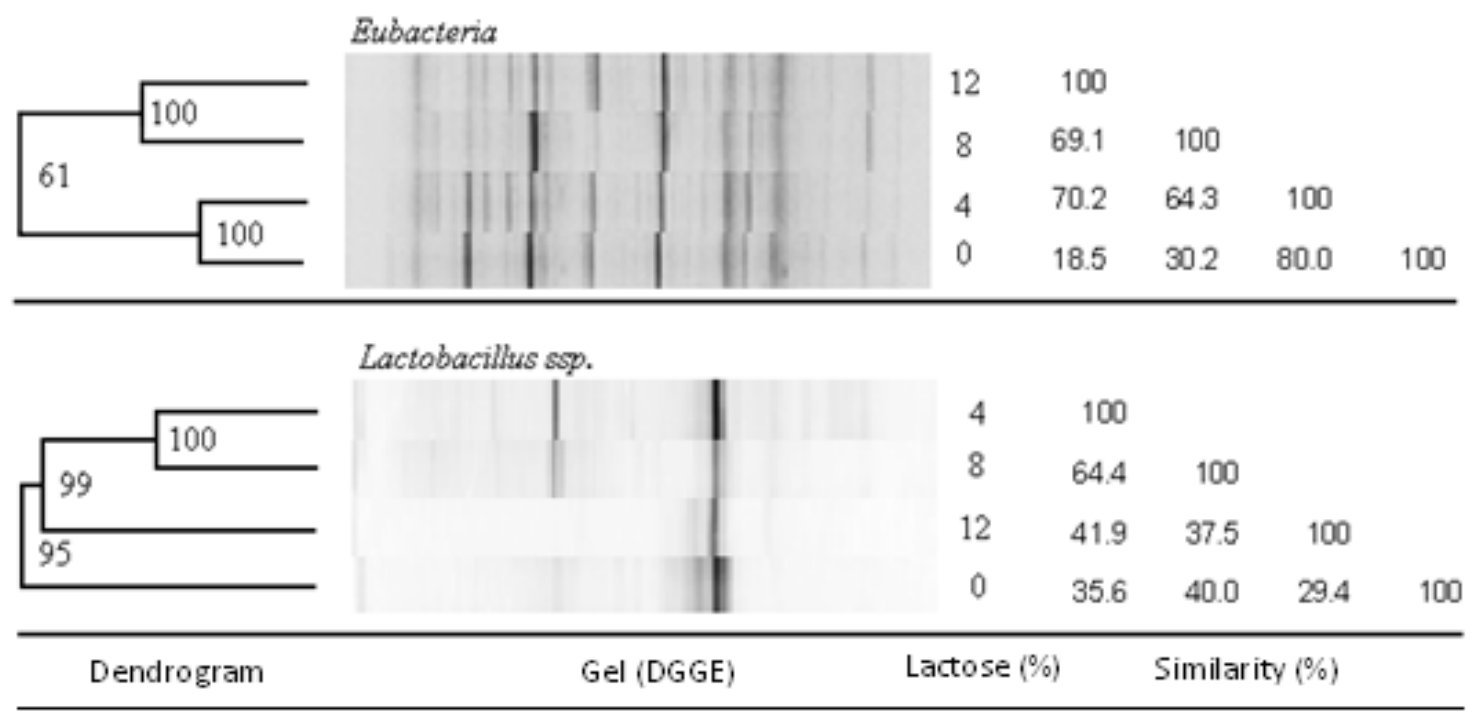

Figure 2 - Dendrogram, DGGE electrophoretic profiles, and similarity (\%) of rDNA16S gene sequences of digesta content from the proximal colon of piglets fed diets with $0,4,8$, and 12\% lactose for Eubacteria and Lactobacillus spp.

However, corroborating the results of richness, diversity, and equitability obtained (Figure 1) that suggest the occurrence of inhibition of some Lactobacillus spp. groups when the level of lactose in the diets increased from 8 to $12 \%$, the similarity observed among the groups of piglets fed diets with $12 \%$ lactose and those fed diets containing 4 and $8 \%$ lactose was of 41.9 and 37.5 respectively, which is considered low.

The lowest similarity observed for Lactobacillus spp. (29.4\%) was observed in the microbiota of piglets fed diets containing 0 and $12 \%$ lactose.

These results indicate that even if the microbial analysis for Lactobacillus spp. of digesta of piglets which were fed diets with 0 and $12 \%$ lactose has shown the lowest indexes of richness, diversity, and equitability (Figure 1), the intestinal microbial populations of these two groups of pigs were not similar.

Other research works have contributed to confirm that the type of ingredient used in the diet has an effect on the intestinal microbiota of piglets and it may reflect in their performance (Willians et al., 2001; Krause et al., 1995). Some oligosaccharides, such as fructo-oligosaccharides, mannan oligosaccharide and galactoligosaccharides are called prebiotics because they increase, selectively, health bacteria as Lactobacillus spp. and Bifidobacteria spp. which are known to inhibit the growth of other pathogenic microorganisms (Liu et al., 2008).

Results reported by Krause et al. (1995) in a study evaluating the effect of the diet on the microbiota of piglet pointed out the need to deepen the knowledge in microbial ecology and microorganism diversity along the gastrointestinal tract and how they interact with the diet and the body.

In the study of these authors, although there was no difference in the diversity index of Shannon-Weaver of the intestinal microbiota among the groups fed diets mainly composed of corn and soybean meal with 0 or $40 \%$ lactose, the agar culture of the intestinal content of piglets for 12 species of Lactobacillus proved to be quite varied as observed in this work.

Particularly in the nutrition of piglets, the studies of Delcenserie et al. (2008) and Bandeira et al. (2007) pointed to the need to consider the effects of the ingredients used in the diets on the microbiota of piglet and its relationship with the immune system activation inasmuch as the inflammatory response may negatively influence the partition of nutrients in the body (Machado \& Fontes, 2005).

The species of microorganisms composing the bacterial community reproduce in accordance to the diet composition, especially in fermentable carbohydrates (Wang et al., 2007; Janczyk et al., 2007; Konstantinov et al., 2004).

As most ecosystems of microorganisms existing are not cultivable (Handelsman, 2004), metagenomic studies have been an important tool to elucidate which groups of microorganisms in the digestive tract of pigs can bring benefits reflected on performance of animals.

Although it was not possible to verify differences $(\mathrm{P}>0.05)$ in performance or intestinal morphology when dietary lactose increased from 0 to $12 \%$ in this study, it can be suggested, based on the data from the gut microbial 
composition, that the animals fed diets containing up to $8 \%$ lactose may be better prepared to face higher health challenge, as it commonly occurs in commercial pig farms.

\section{Conclusions}

Lactose levels do not influence performance of piglests and intestinal morphology. The best intestinal microbiota composition of piglests is obtained at $8 \%$ of lactose.

\section{References}

BANDEIRA, C.M.; FONTES, D.O.; SOUZA, L.P.O. et al. Saúde intestinal dos leitões: um conceito novo e abrangente. In: SIMPÓSIO DE SUINOCUlTURA, 2., 2007, Lavras. Anais... Lavras: UFLA, 2007. p.85-123.

BERTOL, T.M.; SANTOS FILHO, J.I.; LUDKE, J.V. Níveis de suplementação com lactose na dieta de leitões desmamados. Revista Brasileira de Zootecnia, v.29, n.5, p.1387-1393, 2000 .

BUFFINGTON, D.E.; COLAZZO-AROCHO, A.; CANTON, G.H. et al. Black globe-humidity index (BGHI) as comfort equation for dairy cows. Transaction of the ASAE, v.24, n.3, p.711-714, 1981

CAMPOS, J.A.; TINÔCO, I.F.F.; BAÊTA, F.C. et al. Ambiente térmico e desempenho de suínos em dois modelos de maternidade e creche. Revista Ceres, v.55, n3, p.187-193, 2008.

CROMWELL, G.L.; ALEE, G.L.; MAHAN, D.C. Assessement of lactose levels in the mid- to late-nursery phase on performance of weanling pigs. Journal of Animal Science, v.86, n.1, p.127-133, 2008 .

DELCENSERIE, V.; MARTEL, D.; LAMOUREUX, M. et al. Immunomodulatory effects of probiotics in the intestinal tract. Current Issues Molecular Biology v.10, n.1-2, p.37-54. 2008 .

DILlY, O.; BLOEM, J.; VOS, A. et al. Bacterial diversity in agricultural soils during litter decomposition. Applied and Enviromental Microbiology, v.70, n.1, p.468-474, 2004.

HANDELSMAN, J. Metagenomics: application of genomics to uncultured. Microbiology and Molecular Biology Reviews, v.68, n.4, p.669-685, 2004.

HERDT, T. Fisiologia gastrointestinal e metabolismo. In: CUNNINGHAM, J.P. (Ed.) Tratado de fisiologia veterinária. 2.ed. Rio de Janeiro: Editora Guanabara, 1999. p.213-305.

JANCZYK, P.; PIEPER, R.; SMIDT, H. et al. Changes in the diversity of pig ileal lactobacilli around weaning determined by means of $16 \mathrm{~S}$ rRNA gene ampliccation and denaturing gradient gel electrophoresis. Federation European Microbiology Societies, Microbiologic Ecology, v.61, n.1, p.132-140, 2007

KONSTANTINOV, S.R.; AWATI, A.; SMIDT, H. et al. Specific response of a novel and abundant Lactobacillus amylovorusLike phylotype to dietary prebiotics in the guts of weaning piglets. Applied And Enviromental Microbiology, v.70, n.7, p.3821-3830, 2004.

KRAUSE, D.O.; EASTER, R.A.; WHITE, B.A. et al. Effect of weaning diet on the ecology of adherent lactobacilli in the gastrointestinal tract of the pig. Journal of Animal Science, v.73, n.8, p.2347-2354, 1995 .

LIU, P.; PIAO, X.S.; KIM, S.W. et al. Effects of chitooligosaccharide supplementation on the growth performance, nutrient digestibility, intestinal morphology, and fecal shedding of Escherichia coli and Lactobacillus in weaning pigs. Journal of Animal Science, v.86, n.10, p.2609-2618, 2008
LU, J.; IDRIS, U.; HARMON, B. et al. Diversity and succession of the intestinal bacterial community of the maturing broiler chicken. Applied and Environmental Microbiology, v.69, n.11, p.6816-6824, 2003.

LYNCH, B.; CALLAN, J.J.; O'DOHERTY, J.V. The interaction between dietary crude protein and fermentable carbohydrate source on piglet post weaning performance, diet digestibility and selected faecal microbial populations and volatile fatty acid concentration. Livestock Production Science, v.124, n.1, p.93-100, 2009.

MACHADO G.S.; FONTES, D.O. Relação entre as exigências nutricionais e o sistema imune em suínos. In: SIMPÓSIO INTERNACIONAL SOBRE EXIGÊNCIAS NUTRICIONAIS DE AVES E SUÍNOS, 2., 2005, Viçosa, MG. Anais... Viçosa, MG: UFV, 2005, p.293-314

MAHAN, D.C.; FASTINGER, N.D.; PETERS J.C. Effects of diet complexity and dietary lactose levels during three starter phases on postweaning pig performance. Journal of Animal Science, v.82, n.9, p.2790-2797, 2004.

MUYZER, G.; DE WALL, E.C.; UITTERLINDEN, A.G. Profiling of complex microbial populations bydenaturing gradient gel electrophoresis analysis of polymerase chain reaction amplified genes coding for $16 \mathrm{~s}$ rRNA. Applied and Environmental Microbiology, v.59, n.3, p.695-700, 1993.

NARANJO, V.D.; BIDNER, T.D.; SOUTHERN, L.L. Comparison of dried whey permeate and a carbohydrate product in diets for nursery pigs. Journal of Animal Science, v. 88 , n.5, p.1868-1879, 2010.

O'CONNELL, J.M.; CALLAN, J.J.; O'DOHERTY, J.V. The interaction between cereal type and lactose level on piglet performance and diet digestibility post weaning. British Society of Animal Science, v. 81, n.2, p.265-269, 2005.

ODUM, E.P. Ecologia. Rio de Janeiro: Editora Guanabara Koogan, 1993. 474p.

PEDROSO, A.A.; OETTING, L.L.; UTIYAMA, C.E. et al. Variabilidade espacial da comunidade bacteriana intestinal de suínos suplementados com antibióticos ou extratos herbais Revista Brasileira de Zootecnia, v.34, n.4, p.1225-1233, 2005.

PIERCE, K.M.; SWEENEY, T.; BROPHY, P.O. et al. The effect of lactose and inulin on intestinal morphology, selected microbial populations and volatile fatty acid concentrations in the gastrointestinal tract of the weanling pig. Animal Science, v. 82 , n.3, p.311-318, 2006.

PIERCE, K.M.; CALLAN, J.J.; McCARTHY, P. et al. The interaction between lactose level and crude protein concentration on piglet post-weaning performance, nitrogen catabolism and faecal volatily fatty acid concentrations. Animal Feed Science and Technology, v.132, n.3-4, p.267-282, 2007.

PIERCE, K.M.; CALLAN, J.J.; McCARTHY, P. et al. Performance of weanling pigs offered low or high lactose diets suplplemented with avilamycin or inulin. British Society of Animal Science, v. 80, n.3, p.313-318, 2005

PLUSKE, J.R.; HAMPSON, D.J.; WILLIAMS, I.H. Factors influencing the structure and function of the small intestine in the weaned pig: a review. Livestock Production Science, v.51, n.1-3, p.215-236, 1997.

PLUSKE, J.R.; THOMPSON, M.J.; ATWOOD, C.S. et al. Maitenance of villous height and crypt depth, and enhancement of disaccharide digestion and monossacharide absoption, in piglets fed on cow's whole milk after weaning. British Journal of Nutrition, v.76, n.3, p.409-422, 1996.

POLLMANN, D.S.; DANIELSON, D.M.; PEO JUNIOR, E.R. Effect of Lactobacillus spp. acidophilus on starter pigs fed a diet supplemented with lactose. Journal of Animal Science, v.51, n.3, p.638-644, 1980.

ROSTAGNO, H.S.; ALBINO, L.F.T.; DONZELE, J.L. et al. Tabelas brasileiras para aves e suínos: composição de alimentos e exigências nutricionais. Viçosa, MG: Universidade Federal de Viçosa, 2005. 186p. 
SPREUWENBERG, M.A.M.; VERDONK, J.M.A.J.; GASKINS, H. R. et al. Small intestine epithelial barrier function is compromised in pigs with low feed intake at weaning. Journal of Nutrition, v.131, n.5, p.1520-1527, 2001.

STEWART, C.A.; HILLMAN, K.; MAXWELL, F. et al. In: Recent advances in animal nutrition. In: GARNSWORTHY, P.C.; COLE, D.J.A. (Eds.) Notthinghan: Nottingham University Press, 1993. p.197-220.

TOUChetTe, K.J.; CROW, S.D.; AlleE, G.L. et al. Lactose response is dependent on plasma in the diet of weaned pigs. Journal of Animal Science, v.73 (suppl.1), n.1, p.171, 1995.

UNIVERSIDADE FEDERAL DE VIÇOSA - UFV. Sistema de análises estatísticas e genéticas - SAEG. Versão 8.1. Viçosa, MG, 2001. 142p.

VENTE-SPREEUWENBERG, M.A.M.; VERDONK, J.M.A.J.; VERSTEGEN, M.W.A. et al. Villous height and gut development in weaned piglets receiving diets containing either glucose, lactose and starch. British Journal of Nutrition, v.90, n.5, p.907-913, 2003.

WANG, H.F.; ZHU, W.Y.; YAO, W. et al. DGGE and 16S rDNA sequencing analysis of bacterial communities in colon content and feces of pigs fed whole crop rice. Anaerobe, v.13, n.3-4 p.127-133, 2007.

WILliAMS, B.A.; VERSTEGEN, M.W.A.; TAMMINGA, S. Fermentation in the large intestine and its relationship to animal health. Nutrition Research Review, v.14, n.2, p.207-228, 2001.

YEN, J.T.; NIENABER J.A.; POND, W. G. Effect of neomycin, carbadox and length of adaptation to calorimeter on performance, fasting metabolism and gastrointestinal tract of young pigs. Journal of Animal Science, v. 65, n.5, p.1243-1248, 1987. 